УДК $631.67: 631.41: 634.11$

DOI 10.30679/2219-5335-2021-1-67-226-241

ОЦЕНКА ВЛИЯНИЯ

КАПЕЛЬНОГО ОРОШЕНИЯ

МИНЕРАЛИЗОВАННЫМИ ВОДАМИ

НА ИЗМЕНЕНИЕ СВОЙСТВ

ЧЕРНОЗЕМА ОБЫКНОВЕННОГО

И СОСТОЯНИЕ НАСАЖДЕНИЙ

ЯБЛОНИ

Попова Валентина Петровна

д-р с.-х. наук

зав. НЦ агрохимии

и почвоведения,

зав. лабораторией экологии почв

Фоменко Тарас Григорьевич

канд. с.-х. наук

зав. ФНЦ «Садоводство»,

зав. лабораторией агрохимии

и мелиорации

e-mail: sad-fertigation@mail.ru

Макарова Алина Алексеевна

младший научный сотрудник

лабораторией агрохимии

и мелиорации

Федеральное государственное

бюджетное научное учреждение

«Северо-Кавказский федеральный

научный иентр садоводства,

виноградарства, виноделия»

Краснодар, Россия

Рассмотрены проблемы трансформации свойств черноземных почв садовых ценозов при капельном поливе минерализованными водами. Широкое внедрение капельного орошения с внесением минеральных удобрений при возделывании плодовых насаждений по интенсивным технологиям создало ряд проблем экологического характера. Вынужденное использование минерализованных вод для полива из-за ограниченности ресурсов способствует изменению свойств черноземов.

В течение последних лет фиксируются
UDC $631.67: 631.41: 634.11$

DOI 10.30679/2219-5335-2021-1-67-226-241

\section{EVALUATION OF EFFECT \\ OF SALINE WATER \\ DRIP IRRIGATION \\ THE CHANGE OF ORDINARY \\ CHERNOZEM'S PROPERTIES \\ AND APPLE PLANTATIONS \\ CONDITION}

Popova Valentina Petrovna

Dr. Sci. Agr.

Head of Agrochemistry

and Soil science SC,

Head of Soil Ecology Laboratory

Fomenko Taras Grigorievich

Cand. Agr. Sci.

Head of FSC «Gardening»,

Head of Agrochemistry

and Melioration Laboratory

e-mail: sad-fertigation@mail.ru

Makarova Alina Alekseyevna

Junior Research Associate

of Agrochemistry

and Melioration Laboratory

Federal State Budget

Scientific Institution

"North Caucasian Federal

Scientific Center of Horticulture,

Viticulture, Wine-making»,

Krasnodar, Russia

The problems of transformation of chernozem soils properties of garden cenoses during drip irrigation with mineralized water are considered. The widespread introduction of drip irrigation with the mineral fertilizers to cultivate fruit plantations using intensive technologies has created a number of environmental problems. The forced use of mineralized water for irrigation due to limited resources contributes to changes in the properties of chernozem soils, in recent years. 
проявления угнетения плодовых растений на фоне постоянного применения фертигаций в интенсивных плодовых насаждениях. Установлено, что капельное орошение насаждений яблони минерализованной водой способствовало накоплению водорастворимых солей в основной зоне увлажнения почвы. Применение многолетнего капельного орошения в плодовых насаждениях привело к постепенному вымыванию ионов кальция из зон локального увлажнения почвы. Доля магния в почвенно-поглощающем комплексе в результате поливов увеличилась до 20,8-32,8 \% от суммы поглощенных оснований. На участке с угнетенными деревьями яблони отмечено более высокое содержание обменного магния в почве по сравнению с насаждениями яблони в удовлетворительном состоянии. Повышенное содержание натрия в поливной воде привело к существенному увеличению его концентрации в местах локализации поливной воды на участках как с угнетенными, так и с деревьями яблони в удовлетворительном состоянии. Содержание обменного натрия в слое почвы 0-30 см под капельницами увеличилось до 0,94-1,74 мг-экв./100 г. почвы. Доля обменного натрия в почвенном поглощающем комплексе в зоне локального увлажнения увеличилась до 3,1-5,3\% от суммы поглощенных оснований, что свидетельствует уже о слабой степени солонцеватости почвы. Анализ продуктивности насаждений сортов яблони указывает на влияние условий произрастания деревьев на урожай и качество плодов, доля влияния почвенных условий составила 81,8-93,6 \%.

Ключевые слова. ОРОШЕНИЕ МИНЕРАЛИЗОВАННЫМИ ВОДАМИ, ТРАНСФОРМАЦИЯ СВОЙСТВ ПОЧВ, ИНТЕНСИВНЫЕ ПЛОДОВЫЕ НАСАЖДЕНИЯ, ЯБЛОНЯ, ЗАСОЛЕНИЕ ПОЧВ, СОЛОНЦЕВАТОСТЬ ПОЧВ
It is manifested fruit plants oppression against the background of the constant use of fertigation in the intensive fruit plantations. It was found that drip irrigation of apple orchards with mineralized water contributed to the accumulation of water-soluble salts in the main zone of soil moisture. The use of long-term drip the irrigation in fruit plantations led to the gradual leaching of calcium ions from the zones of local soil moisture. The proportion of magnesium in the soil-absorbing complex as a result of irrigation increased in 20.8-32.8\% of the amount of absorbed bases. On the plot with oppressed apple-trees, a higher content of exchangeable magnesium in the soil was noted in comparison with apple plantations under a satisfactory condition. The increased content of sodium in irrigation water led to a significant increase in its concentration in the places of localization of irrigation water in areas with both depressed and apple trees in satisfactory condition. The content of exchangeable sodium in the soil layer $0-30 \mathrm{~cm}$ under the droppers increased in 0.94-1.74 mg-eq./100 g. of soil. The share of exchangeable sodium in the soil absorbing complex in the zone of local soil moisture increased in 3.1-5.3\% of the amount of absorbed bases, which indicates a weak degree of soil salinity. Analysis of apple varieties productivity indicates the influence of tree growth conditions the yield and fruit quality, the share of the influence of soil conditions was $81.8-93.6 \%$.

Key words: IRRIGATION

WITH MINERALIZED WATER, TRANSFORMATION OF SOIL PROPERTIES, INTENSIVE FRUIT PLANTATIONS, APPLE-TREE, SALINIZATION OF SOILS, SALINITY OF SOILS 
Введение. Для полноценного роста и развития плодовых растений, а также получения устойчивых урожаев плодов высокого качества, одними из определяющих факторов являются почвенные условия. При возделывании плодовых насаждений интенсивность воздействия на почву значительно больше, поскольку это агроценозы с бессменным возделыванием плодовых культур на одном месте в течение длительного времени. Уровень химикотехногенных воздействий здесь выше, больше объем выноса органических веществ, и усиленная техногенная нагрузка приводит к трансформации свойств почв [1].

Система ведения интенсивного садоводства предусматривает совокупность сложных элементов производственно-технических мероприятий, где одним из важных элементов является капельное орошение с внесением минеральных удобрений [2]. Наряду с положительным эффектом - увеличение продуктивности плодовых растений, улучшение качества плодов, повышение устойчивости растений к засухе - отмечается и отрицательное воздействие орошения. За период полного цикла возделывания плодового сада неизбежно происходит трансформация комплекса свойств почв плодовых насаждений в сторону ухудшения. Наблюдается увеличение содержания растворенных и доступных форм химических соединений для растений, вместе с тем поливы стимулируют минерализацию органического вещества почвы. Также происходит изменение агрофизических и химических свойств почвы, непосредственно в местах увлажнения, что ведет к формированию неоднородности садовых почв [3-8].

Одним из негативных факторов влияния орошения и фертигации в целом является накопление водорастворимых вредных солей в почве. Минеральный состав поливной воды при длительном применении может оказывать существенное влияние на реакцию почвенного раствора садовых орошаемых почв $[5,8]$. В современных плодовых насаждениях для орошения 
Плодоводство и виноградарство Юга России № 67(1), 2021 г.

преимущественно используются артезианские воды, воды степных рек, прудов и др. различных водоемов.

Важным показателем качества оросительной воды является содержание растворенных в ней веществ. Негативное влияние на садовые культуры оказывают токсические соли, такие как карбонаты и гидрокарбонаты натрия, магния, а также хлориды и сульфаты магния, натрия и кальция $[3,7,8]$. Использование оросительной воды такого качества способствует развитию процессов осолонцевания и ощелачивания почв, что неизбежно приведет их к деградации $[9,10]$.

В водах, пригодных для орошения, содержание растворенных солей не должно быть более 0,2 г/л, допустимыми считаются концентрации от 0,2 до 0,5 г/л при отсутствии в воде нормальной соды. Минерализация поливной воды от 0,5 до 1,0 г/л допустима при условии возделывания садов на почвах с хорошим промывным режимом [11].

Установлена зависимость качества поливной воды и изменения химических свойств черноземных почв. Опубликованы работы, где отмечено, что орошение минерализованной водой в течение нескольких лет привело к увеличению общего количества солей в почвах сада и неравномерному распределению водорастворимых солей в местах увлажнения при капельном орошении. Подщелачивание почвы объясняется в большей степени увеличением содержания обменного натрия в почве [7, 9-15].

Широкое внедрение капельного орошения с внесением минеральных удобрений при возделывании плодовых насаждений по интенсивным технологиям создало ряд проблем экологического характера.

Вынужденное использование минерализованных вод для полива изза ограниченности ресурсов способствует трансформации свойств черноземов, в течение последних лет фиксируются проявления угнетения плодовых растений на фоне постоянного применения фертигаций в интенсивных плодовых садах. 
Плодоводство и виноградарство Юга России № 67(1), 2021 г.

В связи с вышеизложенным существует необходимость исследовать влияние капельного орошения минерализованными водами на скорость деградационных процессов черноземных почв на примере чернозема обыкновенного в условиях интенсивных технологий возделывания.

Объекты и методы исследований. Для исследований выбраны насаждения яблони в ООО «Агрофирма «Красный сад» Ростовской области на черноземе обыкновенном: участки с явными признаками угнетения и гибели деревьев и с деревьями в удовлетворительном состоянии. Почвенный покров обследуемых насаждений представлен чернозёмами обыкновенными слабогумусными мощными легкоглинистыми на лессовидных легких глинах. Характерной особенностью этих почв является наличие карбонатов по всему почвенному профилю, слабое вскипание от 10 \% соляной кислоты отмечается с поверхности, а устойчивое - с глубины 30 см.

Обследование показало, что реакция почвенной среды почв в верхнем

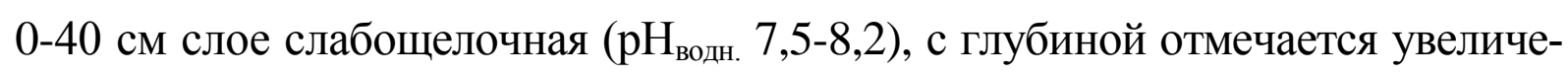
ние показателей до сильнощелочной реакции почвенной среды $\left(\mathrm{pH}_{\text {водн. }} 8,7-8,9\right)$. Содержание органического вещества (гумуса) в верхнем плодородном слое составляет 2,8-3,5 \%, что соответствует среднему уровню обеспеченности.

Для определения качества почвы образцы отбирали с ненарушенным сложением с помощью малогабаритного почвенного бура конструкции С.Ф. Неговелова. Для лабораторного анализа образцы почвы выделяли по слоям 0-40, 40-80, 80-120, 120-160, 160-200 и 200-250 см. Для агрохимического анализа отборы почвенных проб осуществляли тростевым буром в слое почвы 0-30 см непосредственно под капельницами, на расстоянии 20 см и 40 см от точки падения капли раствора питательных веществ при фертигации [16].

Анализ образцов почвы проводили традиционными методами: реакции почвенной среды ( $\left.\mathrm{pH}_{\text {водное }}\right)$ по ГОСТу 26423-85, удельной электропроводности почвы (ЕС) по ГОСТу 26423-85, содержания ионов хлорида и 
ионов натрия потенциометрическим методом в водной вытяжке, содержание общего гумуса по методу Тюрина, содержания нитратов ионометрическим методом по ГОСТу 26951-86; содержания обменного аммония по методу ЦИНАО по ГОСТу 26489-85, содержания подвижных форм фосфора и обменного калия по методу Мачигина в модификации ЦИНАО (ГОСТ 26205-91), обменного кальция и обменного магния трилонометрическим методом в 1,0 н вытяжке $\mathrm{NaCl}$, обменного натрия по ГОСТу 26950-86 [17].

Аналитические работы выполнены на современном аналитическом оборудовании: микроволновая система пробоподготовки МС-6, СВЧ-минерализатор «Минотавр», пламенный фотометр ПФА-354, Спектрофотометр UNICO 2800, LEKISS1207, Капель 104 Р, фотоэлектроколориметр КФО-У4.2, ионометр И-130.2М, влагомер весовой МХ-50, аналитические весы VIBRA, JW-1-3000 Acom и весы аналитические, центрифуги ЛЭ-402, Туре-310, ЦЛН-16, баня водяная LOIPLB-163 (ТБ-6/24-BK), шкаф сушильный СЭШ-1, набор мерной посуды по ГОСТ 1770-64, ГОСТ 20292-74, установка получения деионизированной апирогенной воды «Ключ М-Д», холодильники бытовые (для хранения образцов и реактивов).

Физиолого-биохимические показатели состояния растений яблони, характеризующие метаболическую активность, определяли по методикам, изложенным в методическом пособии [18]. Ростовые процессы яблони, урожайность и качество плодов оценивали по общепринятым методикам [19]. Анализ полученных экспериментальных данных осуществляли методами математической статистики с применением дисперсионного анализа в программе Microsoft Office Excel 2003 [20].

Обсужнение результатов. Основным источником для орошения промышленных садов хозяйства является вода из реки Дон и из скважин глубиной 50-60 м, расположенных вблизи накопительного водоема. В воде определена реакция среды - нейтральная (pH 7,2), общее содержание солей 
составляло 1,770 г/л, из которых доля вредных солей 84,7 \%, при этом содержание хлорида натрия составляло 0,634 г/л. Общее содержание водорастворимых солей превышало оптимальные допустимые значения для полива сельскохозяйственных культур (табл. 1).

Таблица 1 - Химический состав поливной воды, используемой для орошения плодовых насаждений ООО «Красный сад»

\begin{tabular}{|l|c|c|}
\hline \multicolumn{1}{|c|}{ Показатель } & \multicolumn{2}{c|}{ Величина } \\
\hline Реакция среды $(\mathrm{pH})$, ед. & \multicolumn{2}{c|}{7,20} \\
\hline Удельная электропроводность $(\mathrm{Ec})$, мСм/см & \multicolumn{2}{c|}{2,37} \\
\hline \multicolumn{1}{|c|}{ Ионный состав } & мг-экв./л & мг/л \\
\hline Ионы бикарбоната $\left(\mathrm{HCO}_{3}^{-}\right)$ & 10,85 & 385 \\
\hline Ионы хлорида $\left(\mathrm{Cl}^{-}\right)$ & 13,25 & 636 \\
\hline Ионы сульфата $\left(\mathrm{SO}_{4}^{2-}\right)$ & 3,40 & 68 \\
\hline Ионы кальция $\left(\mathrm{Ca}^{2+}\right)$ & 5,10 & 62 \\
\hline Ионы магния $\left(\mathrm{Mg}^{2+}\right)$ & 18,70 & 430 \\
\hline Ионы натрия $\left(\mathrm{Na}^{+}\right)$ & \multicolumn{2}{|c|}{$\mathbf{1 , 7 7 0}$} \\
\hline Сумма солей, г/л & \multicolumn{2}{|c|}{} \\
\hline
\end{tabular}

Для оценки качества поливной воды рассчитано натрий-адсорбционное отношение (SAR - 19,0), которое указывает на высокую вероятность осолонцевания почв при регулярном орошении. В поливной воде установлено высокое содержание ионов натрия (68,8 \% от суммы катионов). Воду такого качества применяют из-за ограниченности водных ресурсов.

Почвы под плодовыми насаждениями на участке с угнетенными деревьями яблони характеризовались нейтральной и слабощелочной реакцией

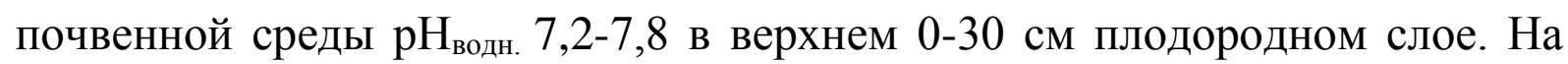
участке с деревьями в удовлетворительном состоянии яблони показатели

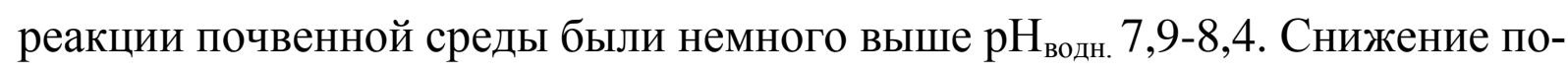
казателей реакции почвенной среды на участке с угнетенными растениями является, скорее всего, следствием почвоутомления и не может являться причиной угнетения деревьев яблони.

Капельное орошение насаждений яблони минерализованной водой способствовало накоплению водорастворимых солей в основной зоне 
увлажнения почвы. Удельная электропроводность почвы под капельницей составляла $0,280-0,415$ мСм/см, что больше по сравнению с параметрами почвы за пределами зоны увлажнения. При этом отмечено, что показатели удельной электропроводности почвы в большей степени зависели от зоны отбора почвенных проб при капельном орошении.

Отмечено повышенное и высокое содержание нитратного азота в зоне локального увлажнения почвы на участке с угнетенными деревьями $23,0-58,0$ мг/кг почвы. На участке с растениями в удовлетворительном состоянии содержание нитратов под капельницами составляло 7,6-33,0 мг/кг почвы. Проведена оценка активности микробиоты почвы на основе оценки степени активности микроорганизмов, разрушающих целлюлозу. Установлено, что активность целлюлозоразрушающих микроорганизмов имела статистически достоверную положительную корреляцию с содержанием нитратов в почве и в большей степени зависела от места отбора почвенных проб в приствольной полосе (рис. 1).

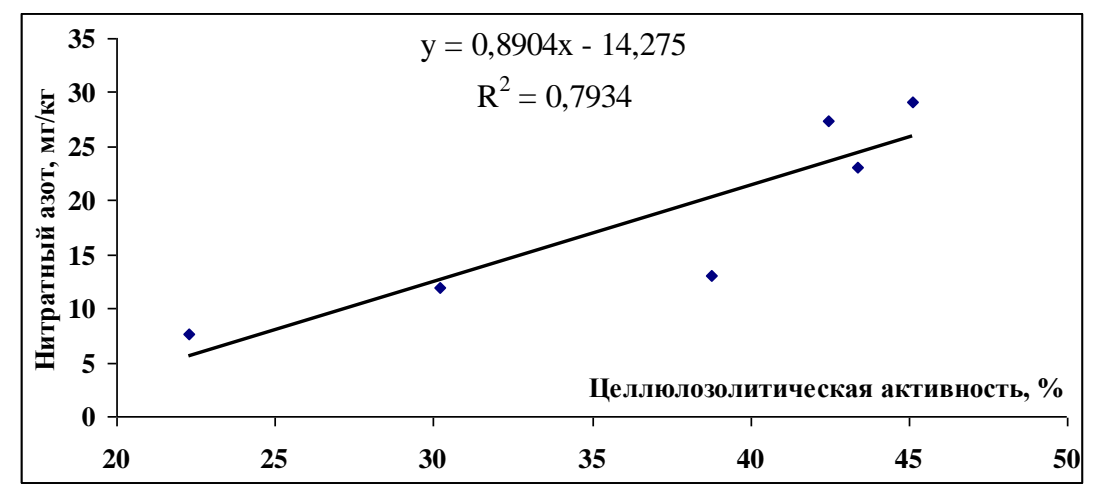

Рис.1. Изменение целлюлозолитической активности почвы в зависимости от содержания нитратного азота

Существенных отличий в содержании нитратного азота, аммиачного азота, органического вещества (гумуса) и целлюлозолитической активности почвы на участках с различным состоянием деревьев не установлено.

Обеспеченность почв плодовых насаждений подвижным фосфором непосредственно под капельницами изменялась от средней 24,6-29,9 мг/кг 
до повышенной 38,4 мг/кг на всех опытных участках. При удалении в сторону междурядий отмечена тенденция увеличения содержания подвижного фосфора, что объясняется локальным внутрипочвенным внесением минеральных удобрений по проекции кроны. В местах локального внесения удобрений содержание подвижного фосфора соответствовало высокому 48,8-57,9 мг/кг и очень высокому уровню обеспеченности - 72,6-158,4 мг/кг.

Уровень обеспеченности обменным калием на обследуемых участках характеризуется как повышенный 385 мг/кг и высокий 430-521 мг/кг.

В целом описываемые почвы характеризуются благоприятными агрохимическими свойствами, что обусловливает довольно высокое их потенциальное плодородие. На обследуемых участках в почве не выявлено явных признаков недостатка основных элементов питания.

Применение многолетнего капельного орошения в плодовых насаждениях привело к постепенному вымыванию ионов кальция из зон локального увлажнения почвы. Снижение содержания обменного кальция в почве в результате орошения составило от 3,16 до 5,78 мг-экв./100 г. почвы непосредственно под капельницами. Следует отметить, что вымывание ионов кальция из зон локального увлажнения почвы установлено на всех обследуемых участках (рис. 2).

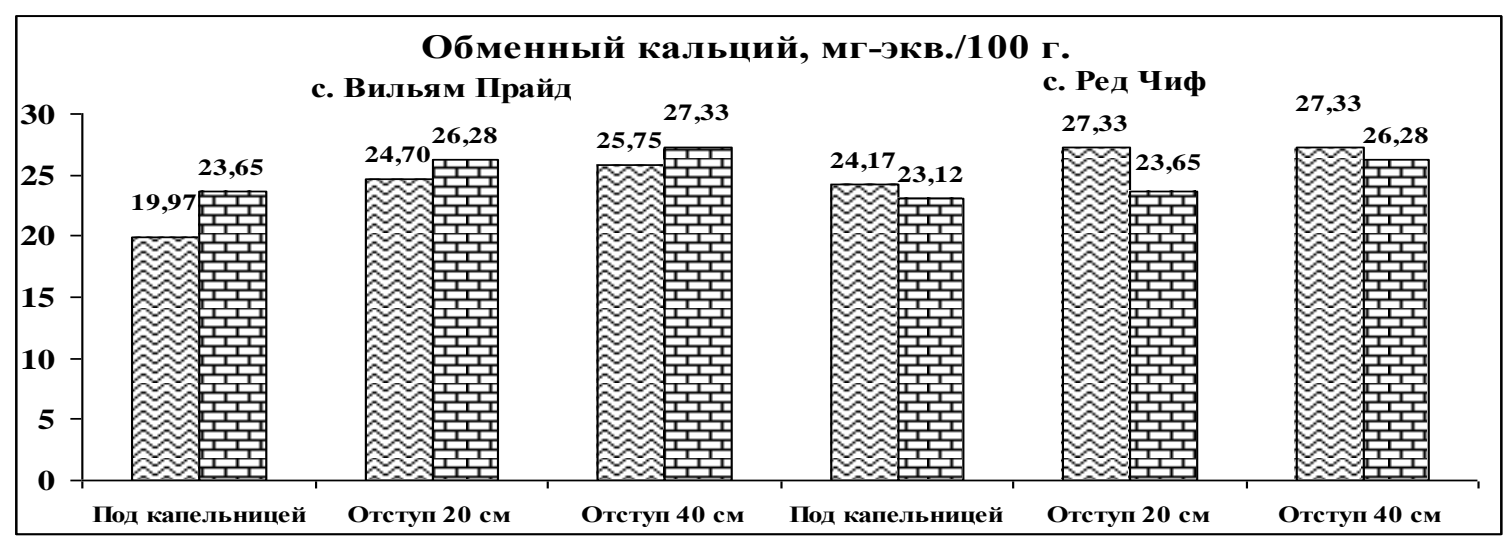

Рис. 2. Содержание обменного кальция в почве насаждений яблони

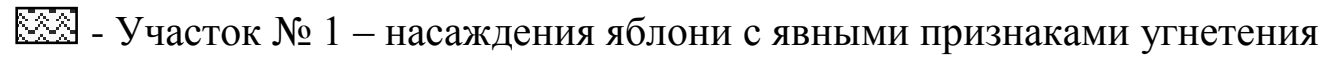
и гибели деревьев;

- Участок № 2 - насаждения яблони в удовлетворительном состоянии. 
Плодоводство и виноградарство Юга России № 67(1), 2021 г.

В зонах локального увлажнения почвы установлено повышение содержания обменного магния до 8,41-10,51 мг-экв./100 г. почвы. В результате доля магния в почвенно-поглощающем комплексе (ППК) на многих участках увеличилась до 20,8-32,8 \% от суммы поглощенных оснований. На участке с угнетенными деревьями яблони отмечено более высокое содержание обменного магния в почве по сравнению с насаждения яблони в хорошем состоянии.

Увеличение обменного магния, вероятно, является следствием применения орошения большими поливными нормами (дождеванием) в предшествующий период при возделывании плодовых насаждений. Магний очень прочно закрепляется в поглощающем комплексе почв и плохо поддается удалению, даже в течение длительного периода. Однако следует отметить, что содержание обменного магния находится в допустимых пределах и вероятно не может являться причиной угнетения деревьев яблони.

Повышенное содержание натрия в поливной воде привело к существенному увеличению его концентрации в местах локализации поливной воды на участках как с угнетенными, так и с деревьями яблони в удовлетворительном состоянии. Содержание обменного натрия в слое почвы 0-30 см под капельницами увеличилось до 0,94-1,74 мг-экв./100 г. почвы. Доля обменного натрия в ППК в зоне локального увлажнения почвы увеличилась до 3,1-5,3 \% от суммы поглощенных оснований, что свидетельствует уже о слабой степени солонцеватости почвы (рис. 3). За пределами зоны локального увлажнения почвы содержание обменного натрия определено как невысокое и не превышало 0,5 \% от суммы поглощенных оснований, что соответствует оптимальным параметрам.

Результаты исследования агрохимических параметров почв показали, что существенных отличий свойств почв на участках с различным состоянием деревьев не выявлено. В целом описываемые почвы характеризуются 
Плодоводство и виноградарство Юга России № 67(1), 2021 г.

благоприятными агрохимическими свойствами, явных признаков недостатка основных элементов питания не установлено.

Для изучения состояния растений яблони определяли водный статус и содержание пигментов в листьях яблони. Оводненность листьев угнетенных деревьев была меньше, чем деревьев в удовлетворительном состоянии. Уровни содержания хлорофиллов А и В, каротина также были ниже в листьях угнетенных растений (табл. 2).

Определение площади листовой пластинки растений яблони с разным состоянием показало, что на угнетенных деревьях развитие листьев заторможено, размер их меньше, в среднем от 6,7 \% до 31,8 \% в зависимости от сорта (рис. 4).
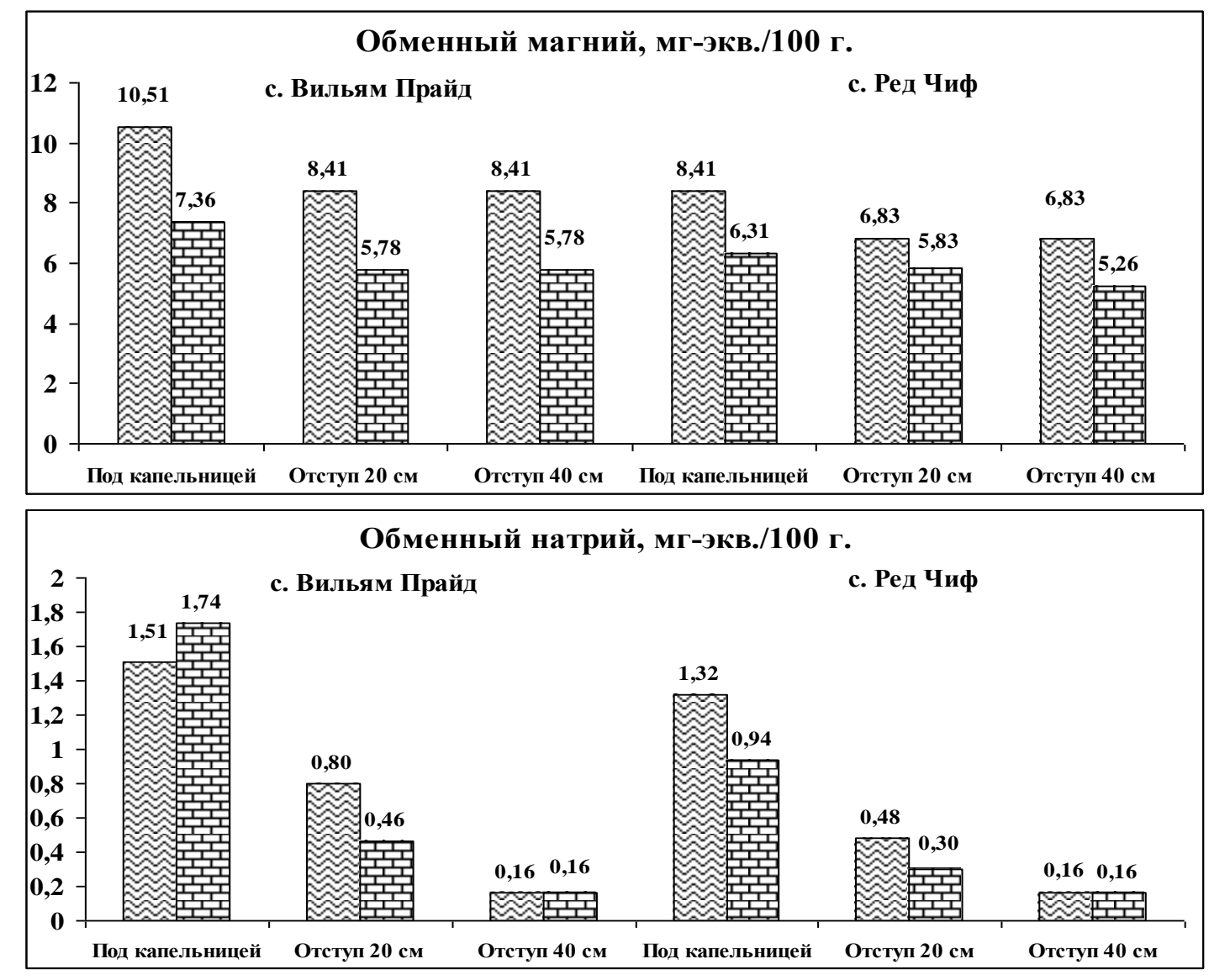

Рис. 3. Изменение свойств почв насаждений яблони

冬 - Участок № 1 - насаждения яблони с явными признаками угнетения и гибели деревьев;

臣 - Участок № 2 - насаждения яблони в хорошем состоянии. 
Плодоводство и виноградарство Юга России № 67(1), 2021 г.

Таблица 2 - Водный режим и содержание пигментов в листьях яблони

\begin{tabular}{|c|c|c|c|c|c|c|c|}
\hline \multirow[t]{2}{*}{$\begin{array}{c}\text { Участок } \\
\text { обследования }\end{array}$} & $\begin{array}{c}\text { Оводнен- } \\
\text { ность }\end{array}$ & $\begin{array}{c}\text { Сухое } \\
\text { вещество }\end{array}$ & $\begin{array}{c}\text { Свободная } \\
\text { вода }\end{array}$ & $\begin{array}{c}\text { Связанная } \\
\text { вода }\end{array}$ & \multicolumn{2}{|c|}{$\begin{array}{l}\text { Содержание } \\
\text { хлорофилла, } \\
\text { мг/г сух. в-ва }\end{array}$} & \multirow{2}{*}{$\begin{array}{c}\text { Каротин, } \\
\text { мг/г сух. } \\
\text { в-ва }\end{array}$} \\
\hline & \multicolumn{4}{|c|}{$\%$} & A & B & \\
\hline \multicolumn{8}{|c|}{ Сорт Вильямс Прайд } \\
\hline $\begin{array}{c}\text { Угнетенные } \\
\text { деревья }\end{array}$ & 49,87 & 50,13 & 33,86 & 66,14 & 2,19 & 0,66 & 1,17 \\
\hline $\begin{array}{c}\text { Деревья } \\
\text { в удовлетвори- } \\
\text { тельном } \\
\text { состоянии } \\
\end{array}$ & 56,72 & 43,28 & 17,29 & 82,71 & 2,86 & 0,90 & 1,44 \\
\hline \multicolumn{8}{|c|}{ Сорт Ред Чиф } \\
\hline $\begin{array}{c}\text { Угнетенные } \\
\text { деревья }\end{array}$ & 55,85 & 44,15 & 17,17 & 82,83 & 4,40 & 1,47 & 1,88 \\
\hline $\begin{array}{c}\text { Деревья } \\
\text { в удовлетвори- } \\
\text { тельном } \\
\text { состоянии }\end{array}$ & 64,90 & 35,10 & 15,13 & 84,87 & 5,66 & 1,88 & 2,43 \\
\hline
\end{tabular}

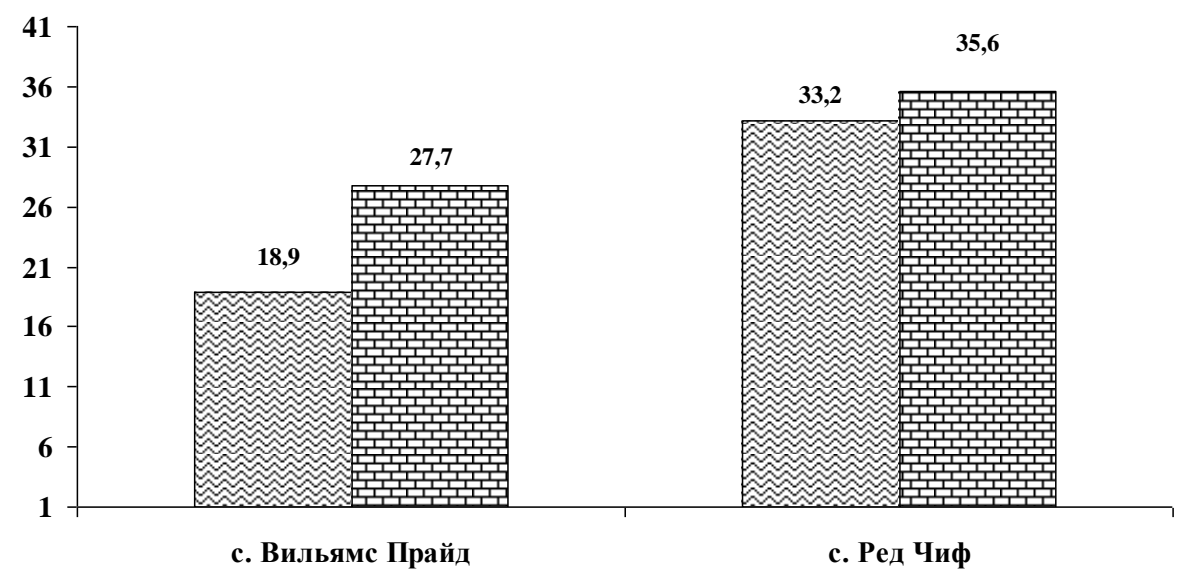

HCP 05

3,5

2,3

Рис. 4. Площадь листовой пластинки деревьев яблони

․․ㅊ - Участок № 1 - деревья яблони с явными признаками угнетения и гибели деревьев; 臣罣 - Участок № 2 - деревья яблони в удовлетворительном состоянии

Анализ продуктивности насаждений яблони указывает на влияние условий произрастания деревьев на урожай и качество плодов. Урожайность яблони сорта Вильямс Прайд и средняя масса плода в большей степени зависели от почвенных условий, доля влияния фактора 81,8-93,6 \% (табл. 3). 
Таблица 3 - Урожайность яблони и размер плодов в зависимости от почвенных условий произрастания

\begin{tabular}{|c|c|c|c|}
\hline Участок обследования & $\begin{array}{c}\text { Средняя } \\
\text { масса плода, } \\
\text { Г }\end{array}$ & \begin{tabular}{|c|} 
Среднее \\
количество \\
плодов \\
на дереве, шт
\end{tabular} & $\begin{array}{c}\text { Урожайность, } \\
\text { т/га }\end{array}$ \\
\hline \multicolumn{4}{|c|}{ Сорт Вильямс Прайд } \\
\hline Деревья яблони с признаками угнетения & 61,7 & 33,2 & 5,1 \\
\hline Деревья яблони в хорошем состоянии & 141,7 & 58,4 & 20,7 \\
\hline $\mathrm{HCP}_{05}$ & 18,8 & 11,8 & 4,5 \\
\hline Критерий Фишера & $\begin{array}{l}F_{\text {факт }}(88,61)> \\
F_{\text {станд } 05}(4,96)\end{array}$ & $\begin{array}{l}\mathrm{F}_{\text {факт }}(27,95)> \\
\mathrm{F}_{\text {станд 05 }}(4,96)\end{array}$ & $\begin{array}{l}F_{\text {факт }}(86,33)> \\
F_{\text {станд } 05}(4,96)\end{array}$ \\
\hline $\begin{array}{l}\text { Доля влияния фактора на изменчивость } \\
\text { признака, \% }\end{array}$ & 93,6 & 81,8 & 93,4 \\
\hline \multicolumn{4}{|c|}{ Сорт Ред Чиф } \\
\hline Деревья яблони с признаками угнетения & - & 25,2 & - \\
\hline Деревья яблони в хорошем состоянии & - & 32,6 & - \\
\hline $\mathrm{HCP}_{05}$ & - & 9,5 & - \\
\hline Критерий Фишера & - & $\begin{array}{l}\mathrm{F}_{\text {фант }}(2,24)< \\
\mathrm{F}_{\text {станд } 05}(4,96)\end{array}$ & - \\
\hline $\begin{array}{l}\text { Доля влияния фактора на изменчивость } \\
\text { признака, \% }\end{array}$ & - & 17,1 & - \\
\hline
\end{tabular}

Таким образом, результаты исследований убеждают, что необходимы более детальные исследования причин угнетения деревьев яблони на черноземах обыкновенных при капельном орошении минерализованными водами, требуется оценка степени почвоутомления при монокультуре в условиях интенсивной технологии возделывания.

Bbыводы. В насаждениях яблони с капельным орошением минерализованными водами на участке с угнетенными деревьями отмечена тенденция снижения показателей реакции почвенной среды и повышение обменного магния в почве по сравнению с насаждениями яблони в хорошем состоянии. Повышенное содержание натрия в поливной воде привело к существенному увеличению его концентрации в местах локализации поливной воды на 
Плодоводство и виноградарство Юга России № 67(1), 2021 г.

участках как с угнетенными, так и с деревьями яблони в удовлетворительном состоянии. Содержание обменного натрия в слое почвы 0-30 см под капельницами увеличилось до 0,94-1,74 мг-экв./100 г почвы. Доля обменного натрия в ППК в зоне локального увлажнения почвы увеличилась до 3,1-5,3 \% от суммы поглощенных оснований, что свидетельствует уже о слабой степени солонцеватости. Анализ продуктивности насаждений яблони указывает на влияние условий произрастания деревьев на урожай и качество плодов, доля влияния почвенных условий составляет 81,8-93,6 \%.

\section{Литература}

1. Попова В.П., Пестова Н.Г., Сергеева Н.Н. Плодородие чернозёма в плодовом саду // Земледелие. 1999. № 3. С. 11.

2. Бузоверов А.В., Попова В.П., Пестова Н.Г. Изменение гумусного состояния и питательного режима почвы в садовом агрофитоценозе в течение жизненного цикла. Краснодар: СКЗНИИСиВ, 1992. 11 с.

3. Попова В.П. Агроэкологические аспекты формирования продуктивных садовых экосистем. Краснодар: СКЗНИИСиВ, 2005. 242 с.

4. Попова В. П. Управление плодородием почв в плодовых ценозах приёмами фитомелиорации [Электронный ресурс] // Плодоводство и виноградарство Юга России. 2010. № 6(5). C. 69-85. URL: http://journalkubansad.ru/pdf/10/05/10.pdf. (дата обращения: 11.01.2021).

5. Chuancheng FU, Haibo ZHANG, Chen TU, Lianzhen LI, Xinghua LIU, Yongming LUO Spatial interpolation of orchard soil $\mathrm{pH}$ using soil type and planting duration as auxiliary information // Pedosphere. - 2018. - №30(5). - C. 628-637.

6. Najme Yazdanpanaha, Ebrahim Pazira, Ali Neshat, Majid Mahmoodabadi, Leonor Rodriguez Sinobas Reclamation of calcareous saline sodic soil with different amendments (II): Impact on nitrogen, phosphorous and potassium redistribution and on microbial respiration // Agricultural Water Management. - 2013. - №120. - C. 39-45.

7. Łukasz Musielok, Marek Drewnik, Mateusz Stolarczyk, Magdalena Gus, Sylwia Bartkowiak, Krzysztof Kożyczkowski, Jakub Lasota, Alicja Motak, Karolina Szczechowska, Mikołaj Wątły Rates of anthropogenic transformation of soils in the Botanical Garden of Jagiellonian University in Krakyw (Poland) // Soil \& Tillage Research. - 2018. - №170. C. 271-282.

8. Martina Angela Caretta, Lars-Ove Westerberg, David Mwehia Mburu, Manuel Fischer, Lowe Bцrjeson Soil management and soil properties in a Kenyan smallholder irrigation system on naturally low-fertile soils // Applied Geography. - 2018. - №90. - C. 248-256.

9. Oussama Mounzer, Francisco Pedrero-Salcedo, Pedro A. Nortes, Josй-Maria Bayona, Emilio Nicolas-Nicolas, Juan Jose Alarcon Transient soil salinity under the combined effect of reclaimed water and regulated deficit drip irrigation of Mandarin trees // Agricultural Water Management. - 2013. - №120. - C. 23-29.

10. Le Qi, Peng Zhou, Laishu Yang, Ming Gao Effects of land reclamation on the physical, chemical, and microbial quantity and enzyme activity properties of degraded agricultural soils // Journal of Soils and Sediments. - 2020. - №20 - C. 973-981. 
11. Система земледелия в садоводстве и виноградарстве Краснодарского края. Краснодар: СКЗНИИСиВ, 2015. 241 с.

12. Фоменко Т.Г., Попова В.П., Пестова Н.Г., Черников Е.А. Пространственная неоднородность почв садовых ценозов в условиях локального применения удобрений и водных мелиораций // Агрохимия. -2015. № 2. С. 13-22.

13. Пугачев Г.Н., Кузин А.И. Некоторые аспекты изменения почвенного плодородия в садах интенсивного и традиционного типа [Опыты в яблоневых садах]. // Агропромышленные технологии Центральной России. 2019. Т.2, № 12. С. 85-101.

14. Фоменко Т.Г., Попова В.П., Пестова Н.Г. Трансформация агрохимических свойств почв плодовых насаждений, возделываемых по интенсивным технологиям [Электронный ресурс] // Плодоводство и виноградарство Юга России. 2018. № 54(6). C. 59-71. URL: http://journalkubansad.ru/pdf/18/06/07.pdf. DOI: 10.30679/2219-5335-20186-54-59-71 (дата обращения: 11.01.2021).

15. Jennifer E. Schmidt, Caitlin Peterson, Daoyuan Wang, Kate M. Scow, Amelie C.M. Gaudin Agroecosystem tradeoffs associated with conversion to subsurface drip irrigation in organic systems // Agricultural Water Management. - 2018. - №202. - C. 1-8.

16. Марков Ю.А. Программа и методика исследований по орошению плодовых и ягодных культур. Мичуринск: ВНИИС им. И.В. Мичурина, 1985. 117 с.

17. Методические рекомендации по лабораторным исследованиям почв / Под. ред. Д.С. Орлова. М, 1988. 289 с.

18. Современные инструментально-аналитические методы исследований плодовых культур и винограда / Под общ. ред. Н.И. Ненько. Краснодар: СКЗНИИСиВ, 2015. С. 7-9, 12-16, 59-87.

19. Программа и методика сортоизучения плодовых, ягодных и орехоплодных культур / Под общ. ред. Е.Н. Седова и Т.П. Огольцовой. Орел: ВНИИСПК, 1999. $608 \mathrm{c.}$

20. Доспехов Б.А. Методика полевого опыта (с основами статистической обработки результатов исследований). 5-е изд., доп. и перераб. М.: Агропромиздат, 1985. $351 \mathrm{c}$.

\section{References}

1. Popova V.P., Pestova N.G., Sergeeva N.N. Plodorodie chernozyoma v plodovom sadu // Zemledelie. 1999. № 3. S. 11.

2. Buzoverov A.V., Popova V.P., Pestova N.G. Izmenenie gumusnogo sostoyaniya i pitatel'nogo rezhima pochvy v sadovom agrofitocenoze $\mathrm{v}$ techenie zhiznennogo cikla. Krasnodar: SKZNIISiV, 1992. $11 \mathrm{~s}$.

3. Popova V.P. Agroekologicheskie aspekty formirovaniya produktivnyh sadovyh ekosistem. Krasnodar: SKZNIISiV, 2005. 242 s.

4. Popova V. P. Upravlenie plodorodiem pochv v plodovyh cenozah priyomami fitomelioracii [Elektronnyj resurs] // Plodovodstvo i vinogradarstvo Yuga Rossii. 2010. № 6(5). S. 69-85. URL: http://journalkubansad.ru/pdf/10/05/10.pdf. (data obrashcheniya: 11.01.2021).

5. Chuancheng FU, Haibo ZHANG, Chen TU, Lianzhen LI, Xinghua LIU, Yongming LUO Spatial interpolation of orchard soil $\mathrm{pH}$ using soil type and planting duration as auxiliary information // Pedosphere. - 2018. - №30(5). - S. 628-637.

6. Najme Yazdanpanaha, Ebrahim Pazira, Ali Neshat, Majid Mahmoodabadi, Leonor Rodriguez Sinobas Reclamation of calcareous saline sodic soil with different amendments (II): Impact on nitrogen, phosphorous and potassium redistribution and on microbial respiration // Agricultural Water Management. - 2013. - №120. - S. 39-45. 
7. Łukasz Musielok, Marek Drewnik, Mateusz Stolarczyk, Magdalena Gus, Sylwia Bartkowiak, Krzysztof Kożyczkowski, Jakub Lasota, Alicja Motak, Karolina Szczechowska, Mikołaj Wątły Rates of anthropogenic transformation of soils in the Botanical Garden of Jagiellonian University in Krakuw (Poland) // Soil \& Tillage Research. - 2018. - №170. - S. 271-282.

8. Martina Angela Caretta, Lars-Ove Westerberg, David Mwehia Mburu, Manuel Fischer, Lowe Bcrjeson Soil management and soil properties in a Kenyan smallholder irrigation system on naturally low-fertile soils // Applied Geog-raphy. - 2018. - №90. S. 248-256.

9. Oussama Mounzer, Francisco Pedrero-Salcedo, Pedro A. Nortes, Josj-Maria Bayona, Emilio Nicolas-Nicolas, Juan Jose Alarcon Transient soil salinity under the combined effect of reclaimed water and regulated deficit drip irrigation of Mandarin trees // Agricultural Water Management. - 2013. - №120. - S. 23-29.

10. Le Qi, Peng Zhou, Laishu Yang, Ming Gao Effects of land reclamation on the physical, chemical, and microbial quantity and enzyme activity properties of degraded agricultural soils // Journal of Soils and Sediments. - 2020. - №20. - S. 973-981.

11. Sistema zemledeliya $\mathrm{v}$ sadovodstve i vinogradarstve Krasnodarskogo kraya. Krasnodar: SKZNIISiV, 2015. $241 \mathrm{~s}$.

12. Fomenko T.G., Popova V.P., Pestova N.G., Chernikov E.A. Prostranstvennaya neodnorodnost' pochv sadovyh cenozov v usloviyah lokal'nogo primeneniya udobrenij i vodnyh melioracij // Agrohimiya. -2015. № 2. S. 13-22.

13. Pugachev G.N., Kuzin A.I. Nekotorye aspekty izmeneniya pochvennogo plodorodiya $\mathrm{v}$ sadah intensivnogo i tradicionnogo tipa [Opyty v yablonevyh sadah]. // Agropromyshlennye tekhnologii Central'noj Rossii. 2019. T.2, № 12. S. 85-101.

14. Fomenko T.G., Popova V.P., Pestova N.G. Transformaciya agrohimicheskih svojstv pochv plodovyh nasazhdenij, vozdelyvaemyh po intensivnym tekhnologiyam [Elektronnyj resurs] // Plodovodstvo i vinogradarstvo Yuga Rossii. 2018. № 54(6). S. 59-71. URL: http://journalkubansad.ru/pdf/18/06/07.pdf. DOI: 10.30679/2219-5335-2018-6-54-59-71 (data obrashcheniya: 11.01.2021).

15. Jennifer E. Schmidt, Caitlin Peterson, Daoyuan Wang, Kate M. Scow, Amelie C.M. Gaudin Agroecosystem tradeoff s associated with conversion to subsurface drip irrigation in organic systems // Agricultural Water Manage-ment. - 2018. - №202. - S. 1-8.

16. Markov Yu.A. Programma i metodika issledovanij po orosheniyu plodovyh i yagodnyh kul'tur. Michurinsk: VNIIS im. I.V. Michurina, 1985. $117 \mathrm{s.}$

17. Metodicheskie rekomendacii po laboratornym issledovaniyam pochv / Pod. red. D.S. Orlova. M, 1988. 289 s.

18. Sovremennye instrumental'no-analiticheskie metody issledovanij plodovyh kul'tur i vinograda / Pod obshch. red. N.I. Nen'ko. Krasnodar: SKZNIISiV, 2015. S. 7-9, 12-16, 59-87.

19. Programma i metodika sortoizucheniya plodovyh, yagodnyh i orekhoplodnyh kul'tur / Pod obshch. red. E.N. Sedova i T.P. Ogol'covoj. Orel: VNIISPK, 1999. 608 s.

20. Dospekhov B.A. Metodika polevogo opyta (s osnovami statistichesko jobrabotki rezul'tatov issledovanij). 5-e izd., dop. i pererab. M.: Agropromizdat, 1985. $351 \mathrm{s.}$ 